Instructions for authors, subscriptions and further details:

http://ijep.hipatiapress.com

\title{
Developing School-relevant Language and Literacy Skills through Dialogic Literary Gatherings
}

Garazi Lopez de Aguileta ${ }^{1}$

1) University of Barcelona, Spain

Date of publication: February $24^{\text {th }}, 2019$

Edition period: February 2019-June 2019

To cite this article: Lopez de Aguileta, G. (2019). Developing Schoolrelevant Language and Literacy Skills through Dialogic Literary Gatherings, International Journal of Educational Psychology. 8(1),51-71. doi: 10.17583/ijep.2019.4028

To link this article: http://dx.doi.org/10.17583/ijep.2019.4028

\section{PLEASE SCROLL DOWN FOR ARTICLE}

The terms and conditions of use are related to the Open Journal System and to Creative Commons Attribution License (CC-BY). 


\section{Developing School-relevant Language and Literacy Skills through Dialogic Literary Gatherings}

Garazi Lopez de Aguileta

University of Barcelona (Spain)

\section{Abstract}

Research in the field of educational linguistics has found that low levels of academic language development negatively affect children's language, reading and writing skills and, therefore, academic achievements. This is more noticeable in students from low SES backgrounds, who traditionally have a lower exposure to academic language. Nevertheless, dialogic learning environments such as Dialogic Literary Gatherings (DLGs), a worldwide educational practice where participants read and debate literary classics in an egalitarian dialogue, contribute to the appearance of school-relevant language and literacy skills. Although multiple studies on DLGs have shown their impact in different levels, including improving vocabulary and reading skills, the emergence of such skills has not been studied in depth yet. This exploratory study aims to analyze the emergence of academic language and literacy skills in 19 students between the ages of 11 and 13 studying in a school in Spain with over $90 \%$ immigrant students. Results show that the egalitarian dialogue in which DLGs are based favors the emergence of school-relevant language and literacy skills, such as judgements and arguments, referential links, or connectives.

Keywords: Dialogic Literary Gatherings, school-relevant language and literacy skills, egalitarian dialogue, universal classics of literature

2019 Hipatia Press

ISSN: 2014-3591

DOI: $10.17583 /$ ijep.2019.4028 


\section{Desarrollando Lenguaje y Competencia Linguística para la Escuela a través de Tertulias Literarias Dialógicas}

Garazi Lopez de Aguileta

University of Barcelona (Spain)

\section{Abstract}

Las investigaciones en el campo de lingüística educativa han encontrado que los bajos niveles de desarrollo del lenguaje académico afectan las habilidades de los niños del lenguaje, lectura y escritura. Esto es aún más evidente en estudiantes de bajos niveles socioeconómicos, quienes tradicionalmente han tenido una menor exposición al lenguaje académico. Sin embargo, las Tertulias Literarias Dialógicas (TLD), una práctica educativa mundial en la que los participantes leen y debaten clásicos literarios en un diálogo igualitario, contribuye a la aparición de habilidades de lenguaje y de competencia lingüística relevantes para la escuela. Aunque muchos estudios sobre TLD han demostrado sus impactos a diferentes niveles, como mejora del vocabulario y habilidades de lectura, la aparición de las habilidades mencionadas no se ha estudiado aún en profundidad. Este estudio exploratorio pretende analizar la aparición de habilidades de lenguaje y competencia lingüística relevantes para la escuela en estudiantes de entre 11 y 13 de una escuela en España con más de 90\% de estudiantes inmigrantes. Los resultados muestran que el diálogo igualitario en el que las TLD se basan favorece la aparición de habilidades de lenguaje y competencia lingüística relevantes para la escuela como juicios y argumentos, referencias, o conectores.

Palabras clave: Tertulias Literarias Dialógicas, habilidades de lenguaje y competencia lingüística relevantes para la escuela, diálogo igualitario, clásicos de la literatura universal

2019 Hipatia Press

ISSN: 2014-3591

DOI: $10.17583 /$ ijep.2019.4028 
s society becomes increasingly dialogic, language and social interaction gain importance in our everyday lives, becoming the center of all human relationships and contexts. Authors such as Vygotsky $(1962,1978)$ and others who have followed his research line (Bakhtin, 1981; Bruner, 1996; Mercer, 2000) have defined learning as occurring both at the personal and social level, mediated by language as a cultural and psychological tool. As children grow up, the communication skills they need to master for successful academic and professional trajectories become more and more complex. Therefore, school should provide them the right skills which will contribute to opening possibilities for them to succeed in social life. Nevertheless, many students face barriers in adult life due to poor academic performance, which closes many doors for their higher academic and professional futures. Research has found that one of the drivers of the lack of academic success is that students do not develop the academic language and literacy skills necessary for reading comprehension, writing and other communicative skills needed to succeed at school (Snow \& Uccelli, 2009; Lawrence et al., 2010; Uccelli et al., 2015b). Moreover, the lower their exposure to language and literacy skills relevant for academic success, the lower their acquisition of such skills. Children living in low SES backgrounds are usually the ones receiving less inputs of school-relevant language and literacy skills (Snow et al., 1998; Uccelli et al., 2015a). All students, regardless of their SES background, ethnicity, gender or age, need to be granted the same educational opportunities, and this includes high-quality interactions with teachers, peers, and academic and literary texts. Dialogic learning environments such as Dialogic Literary Gatherings (DLGs), in which egalitarian dialogue becomes the center, guarantee all children's inherent right to education by providing them with high-quality dialogic spaces in which they read and debate some of the greatest literary human creations (Flecha, 2000). The richness of the literary texts and the egalitarian dialogue which underpins the gatherings provide them with equal opportunities for academic and personal success as reported by several articles (Soler, 2015).

Nevertheless, they are thought to contribute to children's emergence of academic language and literacy skills, although no study has explored in detail these outcomes yet. This exploratory study analyzes the emergence of children's school-relevant language and literacy skills through DLGs. 


\section{Lopez de Aguileta - School-relevant language}

\section{Academic Language Skills and School Achievement}

In the field of language and literacy learning, a number of research has been conducted on the relationship between academic or school-relevant language proficiency and academic achievements (Cummins, 1979; Cummins, 2008; Snow \& Uccelli, 2009; Uccelli et al., 2015a). It has been found that mastering school-relevant language and literacy skills contributes to academic success, and that when students are not proficient in these skills, they have more difficulties to succeed at school (Fang et al., 2006; Snow \& Uccelli, 2009; Uccelli et al., 2015a). Lack of proficiency and understanding of school-relevant language and literacy skills make reading comprehension challenging for students, especially for understanding the academic language of school texts (Uccelli et al., 2015a).

However, academic language proficiency is not only linked with reading comprehension, but also with other school subjects such as math or science, where academic texts are plentiful (Snow \& Uccelli, 2009). Moreover, having difficulties for mastering academic language entails barriers for accessing higher education and a wide range of opportunities outside school, such as health, political and civic information, as society increasingly demands complex communication skills (Fang et al., 2006; Meneses et al., 2017). As Fang, Schleppegrell \& Cox (2006) point out, although acquiring academic language and literacy skills does not automatically provide students with future professional success, a lack of such skills does limit their opportunities and access to future professional and social success. Therefore, it is educational researchers' responsibility to provide knowledge on educational practices that contribute to students' development of academic language skills.

Literature on school-relevant language and literacy skills' development suggests that students need a greater exposure to academic or cognitively demanding texts, as well as explicit learning of language and literacy skills present in such texts (Fang et al., 2006; Lawrence et al., 2010; Uccelli et al., 2015a). As Lawrence, White and Snow (2010) state, teaching and learning of "cross-content, whole-school vocabulary instruction" (p. 23), rather than content-specific vocabulary instruction, could contribute to a greater acquisition of academic language and literacy skills and, thus, to a better understanding of texts. Along the same line, Uccelli et al.'s (2015a, 2015b) construct of CALS (Core Academic Language Skills), which includes 
knowledge of connectives, nominalizations, embedded clauses or structures for organizing texts across content areas, have been found to strengthen reading comprehension. Others point at teaching students strategies for being engaged with school texts easily and with a critical mind (Fang et al., 2006). Research also highlights the need for students' need of multiple exposures and in different contexts to acquire and develop academic language skills in order to learn it (Lawrence et al., 2010).

\section{Lower Access to Academic Language and Literacy Skills in Children from Low SES Backgrounds}

Language, as being socially situated, is learned and developed through interactions and exposure to it, and the same is known for learning and developing academic language skills (Snow et al., 2009; Uccelli et al., 2015a). Studies in the field underline the importance of children to be exposed to and engaged with academically complex texts and discourses throughout all school years in order to acquire school-relevant language and literacy skills (Snow et al., 2009; Uccelli et al., 2015a). That is, children need high-quality texts, instruction and interactions in order to develop academic proficiency and succeed in and outside school (Uccelli et al., 2015a; García-Carrión \& Villardón-Gallego, 2016). Unfortunately, although not exclusively, children from low SES backgrounds have traditionally had limited access to texts of great linguistic richness, such as academic texts or universal classics of literature. They usually have less opportunities to engage and interact with school-relevant texts and discourses, which poses a barrier for them to develop language and literacy skills necessary for educational, personal and social success (Snow et al., 1998; Fang et al., 2006; Uccelli et al., 2015a, 2015b).

Nevertheless, more research is needed to shed light on successful educational practices which contribute to children from low SES backgrounds' development of school-relevant language and literacy skills.

\section{Dialogic Learning Environments Contributing to the Emergence of School-Relevant Language and Literacy Skills: Dialogic Literary Gatherings}

An educational practice which has been found to potentially contribute to children's development of school-relevant language and literacy skills are 


\section{Lopez de Aguileta - School-relevant language}

DLGs. DLGs were identified as a Successful Educational Action (SEA) by the FP6 INCLUD-ED project (2006-2011), the only Social Sciences and Humanities project among the ten selected by the European Commission due to its scientific, political, and social impact. Breaking down elitist walls, DLGs bring some of the greatest literary creations closer to everyone regardless of their SES background, age, level of academic studies or ethnicity.

Dialogic reading has proved to promote language and learning, especially when students talk about what they have read and receive feedback regarding their interpretations and ideas (Valdez-Menchaca \& Whitehurst, 1992). It is especially beneficial for improving reading comprehension skills, which are increasingly complex in school and, therefore, essential to succeed academically (Goldman, 2012). DLGs are a type of dialogic reading activity currently being implemented in more than 3000 diverse schools and other centers all over the world, from favelas in Brazil (Mello \& Braga, 2018) to high SES schools in Cambridge (GarcíaCarrión, 2015) or prisons (Alvarez et al., 2018) and mental health centers in Spain. However, their impacts have been especially noticeable in linguistically and culturally diverse schools, where access to rich texts and dialogues has traditionally been denied. The egalitarian dialogue underlying DLGs and the dialogic reading of universal classics favor a dialogic learning environment in which participants read and debate universal issues and profound feelings which have moved humankind from Ancient Greece, as in The Odyssey or The Iliad, written by Homer in the VIII century BC.

In DLGs, students read and debate a previously agreed upon fragment of high-quality age-appropriate versions of classic literature. Although in children's case the texts are adapted to their age, these versions do not use childish language and stay faithful to the main storylines of the classics. While reading at home and, in some cases, at school, they need to choose a paragraph and develop reasoning on why they have chosen that paragraph. During the DLG sessions, students voluntarily share the paragraph they have chosen and argue why they have done so, and then the rest of students start debating on that paragraph or idea the student has raised. The aim of the DLGs is not to reach an agreed interpretation of the book or finding the author's intended meaning; rather, it is to reflect and find meaning on participants' own lives and experiences through the classic texts and the 
egalitarian dialogue (Soler, 2015). Therefore, the more diverse the voices participating in the DLGs, the richer the debate and the interpretations of the texts.

An indispensable aspect of DLGs is that interactions based on egalitarian dialogue prevail (Soler, 2015). This means that when participants read the paragraphs they have chosen and the reasons why, their interpretations must always be based on arguments instead of on power positions (Serrano et al., 2010; Oliver \& Gatt, 2010). In other words, no student's interpretation is more valid than anyone else's, no matter what their power status, academic level, ethnicity or nationality is, as long as they are always based on respect and supported by arguments (Habermas, 1984). This dialogic learning (Flecha, 2000) framework promotes freedom and respect towards diversity, thus contributing to overcoming inequalities and creating more egalitarian social structures (Serrano et al., 2010). Moreover, the egalitarian dialogue forces students to always look for reasoning and arguments behind their ideas and interpretations, preparing them for an increasingly dialogic and democratic society.

A number of publications have provided evidence on DLGs' academic impacts in improving vocabulary acquisition (Hargreaves \& GarcíaCarrión, 2016; Garcia Yeste et al., 2017); developing reading and speech skills (de Botton et al., 2014); increasing teacher-student talk ratio in classrooms to $75 \%$ (Hargreaves \& García-Carrión, 2016); widening cultural and historical knowledge while improving participants' families' literacy and reading skills (de Botton et al., 2014). Other studies have highlighted the transformations in participants' lives and relationships such as social inclusion (Flecha et al., 2013) empowering participants to overcome inequalities and barriers (Aubert, 2015); promoting children's prosocial behavior (Villardón-Gallego et al., 2018); or increasing values such as respect, tolerance and solidarity among participants and their social environments outside school (García Yeste et al., 2017).

However, there is a gap in the literature on DLGs and dialogic reading regarding, specifically, the development of school-relevant language and literacy skills through DLGs in children living and studying in low SES environments. This exploratory study aims at contributing evidence on the emergence of academic language and literacy skills in children from low SES backgrounds through their participation in DLGs. 


\section{Materials and Methods}

\section{Design}

This study focuses on the analysis of the emergence of school-relevant language and literacy skills in DLGs carried out in a School as Learning Community located in one of the poorest neighborhoods at the outskirts of Terrassa, a large municipality in Catalonia (Spain). The Learning Community has $98 \%$ student diversity, most of them from Muslim or Roma communities, and many students belong to unstructured families at risk of social exclusion. Yet, after it started implementing DLGs and other SEAs 18 years ago, students achieving in reading comprehension in standardized tests went from $17 \%$ to $85 \%$. In 2018 it won the Education Award from the Economy Circle [Círculo de Economía].

In order to achieve its objectives, this study has used the Communicative Methodology of Research as it not only describes reality but, through the inclusion of participants' voices throughout the whole process, it makes an analysis of reality which provides actions and elements that contribute to overcoming inequalities and transforming their lives and social contexts (Gómez, Puigvert \& Flecha, 2011; Soler, 2015). In CMR, researchers establish an egalitarian dialogue with participants in which the former bring the existing scientific evidence on the issue being studied and the latter bring their own experience and cultural intelligence (Flecha, 2014).

\section{Participants}

The study's participants the students from the school's 6th grade class, made up by 6 girls and 13 boys between the ages of 11 and 13, from Spanish, Moroccan and Ecuadorian nationalities.

\section{Procedure}

Two DLG sessions have been observed inductively in March and May 2017. Participants read and commented an age-appropriate Spanish adaptation of Homer's "The Iliad". Previous to the sessions, participants read at home the pages agreed upon and selected a fragment they wanted to share with their classmates, writing down the arguments for choosing such fragments. Moreover, a weekly session, prior to the DLG session as well, 
was dedicated in class to reading the pages, selecting the fragment and elaborating the argument with the teacher's help. During the DLGs, students shared their selected fragments in an egalitarian dialogue moderated by the teacher, while the researcher, who was familiar with the school's staff and students, was observing and audio-recording the sessions.

Once the Principal gave permission for the study to be carried out, students' parents and the teacher were informed about its nature and purpose, and that participation was anonymous and voluntary, giving students the opportunity to request audio-recordings to be stopped at any moment of the study. Informed written consents for the audio-recordings from students' parents were achieved through the school's Principal. A total of 1 hour and 26 minutes have been recorded, transcribed and analyzed for the purpose of this study.

\section{Data Analysis}

Audios from both DLG sessions were transcribed, meticulously read several times, and analyzed and classified into the categories defined for the purpose of this study. Categories were defined based on an extensive literature review in the field of academic and school-relevant language and literacy skills, and on specific data gathered for this study. First, some of the main articles in the field have been reviewed in order to determine the elements/characteristics of academic and school-relevant language and literacy skills they use and mention in their works. Next, a first list of the 20 most recurrent skills in the different publications was gathered. After the initial list was made, both transcriptions were read several times looking, one by one, for each of the skills. From the 20 initial elements, seven were found throughout the DLGs.

The skills that composed the final classification are: Nominalization, Connectives, Morphologically Derived Words, Referential Links, Construction of Judgement and Value, and Arguments. Table 1 shows the seven elements and the reviewed literature in which they have been found. Once the categories that were going to be analyzed in the DLGs were defined, both transcriptions were read again, and elements in the transcriptions which fit any of the categories set out were classified upon them. 
60 Lopez de Aguileta - School-relevant language

Table 1. Academic language skills identified in the literature

\begin{tabular}{lcccc}
\hline & $\begin{array}{l}\text { Uccelli et al., } \\
2015\end{array}$ & $\begin{array}{l}\text { Snow \& } \\
\text { Uccelli, 2009 }\end{array}$ & $\begin{array}{l}\text { Fang et al., } \\
2006\end{array}$ & $\begin{array}{l}\text { Meneses } \\
\text { et al., } \\
2017\end{array}$ \\
\hline Nominlization & $\mathrm{X}$ & $\mathrm{X}$ & $\mathrm{X}$ & $\mathrm{X}$ \\
Connectives & $\mathrm{X}$ & $\mathrm{X}$ & & $\mathrm{X}$ \\
Derived words & $\mathrm{X}$ & & & $\mathrm{X}$ \\
Referential links & $\mathrm{X}$ & & $\mathrm{X}$ & \\
$\begin{array}{l}\text { Construction of } \\
\text { judgement and value }\end{array}$ & & & & \\
Arguments & $\mathrm{X}$ & $\mathrm{X}$ & $\mathrm{X}$ & $\mathrm{X}$ \\
Discourse structure & $\mathrm{X}$ & $\mathrm{X}$ & $\mathrm{X}$ & $\mathrm{X}$ \\
\hline
\end{tabular}

\section{Results}

The data analysis reveals the appearance of many of the school-relevant language and literacy skills that children from low SES backgrounds traditionally lack. Having access to, reading, and collectively reflecting on universal classics such as The Iliad gives them the opportunity to connect, order and express ideas which both the text and their classmates' interactions strengthen. Moreover, the egalitarian dialogue in which DLGs are centered, based on arguments rather than on positions of power, forces/encourages them to always look for an argument to support their ideas and opinions. Indeed, 58 out of the 167 student interactions analyzed in this study either contain a judgement, value, or argument. Observations of the DLGs show the emergence of the following school-relevant language 
and literacy skills: judgements and arguments, referential links, discourse structure and grammatical skills such as nominalization, connectives and derived words.

\section{Constructing Judgements and Arguments: 'I Agree with Aquiles because...'}

Students at the DLGs are used to constructing and formulating judgements and values regarding the passages they read, often showing disagreement with the texts or the characters. When students read and comment them in the DLGs, they learn to situate them in a specific period of time which is often far away from current society. When reading passages that show such values, they often express their opinions against them. For instance, when discussing the slaves that Aquiles is offered in return for going to war against Trojans, children showed their disagreement and rejection towards the matter, and started a debate on equality among women and men: "I think women have their right to give an opinion and that men wouldn't like to be treated the way they treat women"

Following the same debate, children continued discussing differences and equalities among women and men, arguing we all deserve to be treated with equal respect.

I think men are equal to women, ok? There is no difference, physical, of course, there are some physical differences, but you know, in the inside we're all the same, and we all like to be treated with respect and we don't like being nobody's slaves

Moreover, when constructing judgements, they are usually supported with arguments. Indeed, one of the principles of DLGs is egalitarian dialogue, therefore students know their opinions must be based on arguments, as can be seen when a student argues why he thinks Agamenón has not been responsible.

Agamenon hasn't been responsible because he tries to escape

As these examples illustrate, they often disagree with the actions carried out by the books' characters, as the following quote regarding The Iliad and slaves shows. 
I don't agree because he's using slaves as if they were horses or currency and moreover, what are the gifts worth for if his own mother says he's going to die?

This egalitarian dialogue in which the interactions among participants are based promotes participation and expressing one's opinion with the assurance that no one is going to laugh at them or that no one's opinion is going to be valued more than anyone else's, unless opinions are based on power positions. Therefore, students feel free to express whatever opinion they might have, even if it is opposite to a classmate's opinion, as they know that all voices will be respected. When discussing whether women can currently go to war or not, most participants supported the idea that anyone, regardless of their gender, could go to war. Nevertheless, a student argued that men did not want women to go to war because of their wellbeing.

If you want to go to war you can go, I mean you have permission to go, but I think men, I mean they do it for your own good, they don't want you to get hurt and... I mean they don't want you to get hurt, they want you and your children to be safe. I think that's whythey don't let you

\section{Making Referential Links to Classmates and the Texts: 'As my Classmate Said',}

As seen in the previous example, students are used to commenting on their classmates' opinions. In fact, after someone reads aloud the fragment they have chosen and explains the reason for that, the rest of the students are given the opportunity to comment on what their classmates have just said. In the following quote, during the same debate on slavery and equality among women and men, a student picked up on what some of his classmates said to support his disagreement with Agamenón in selling his daughters: "I agree with Mohammed, women are very important, and also with Bryan, who said that Agamenón is selling one of his daughters and that I wouldn't sell one of my daughters".

Another classmate also supported his arguments with a classmates' opinion on why they do not want women to go to war: "As my classmate 
Khadija has said, we don't want them to go to war because, so that they don't get hurt and all that".

Students are also used to making references to what they are reading, to the passages and characters from the books. They base their opinions on what they have read, constantly making references to the paragraphs or pages they are debating. Thus, references such as "in this paragraph Ulises..." or "in previous paragraphs..." are common throughout the DLG sessions.

When students read the texts at home, they often find connections to their own lives and experiences. During the DLGs, they are encouraged to relate the readings with their lives or current society, learning to develop a critical attitude towards what they have seen and experienced. One of the students compared women's work and position in society as portrayed in the book with their role in current society.

Currently, things have changed a lot because women now, let's say, not in everything, but I don't know, I don't know how to tell you, but they do more work than boys, and they are more, a little bit more important than boys

When discussing Patroclo's funeral, which was celebrated with sports and games, many children were surprised as it seemed more like Olympic games (as students referred to the funeral) rather than a funeral, and started a debate comparing each of their diverse cultural traditions of funerals.

The day my father died (...) we, at home, put a candle for him and we can't play music nor laugh because, I mean, it's like a lack of respect for the person who has died because he'll think we're celebrating his death, that we're not interested in him (...) for me (...) the Olympic games when someone has died are like a lack of respect and to say that I don't care he has died, so I think it's very wrong

In cases like this group of $6^{\text {th }}$ grade of primary education, in which students have participated in many DLGs and therefore have read many classics, they sometimes make references to other classics they have 
previously read. In this particular case, three years earlier they had read The Odyssey, with some characters such as Ulysses, so it is easy for them to connect both texts.

As we have seen when we read The Odyssey, in 3rd grade, we have seen he [Ulysses] is very intelligent. In here, in The Iliad, he should be more intelligent. If he [Agamenon] tells someone to go back by offering him gifts and this, Ulises should tell him something, right?

\section{Following a Discourse Structure: 'Second, Gifts are Useless because He's Going to Die'}

In some interactions, elements of discourse order and structure have been seen when constructing judgements and arguments, as can be appreciated in the following example regarding the debate on slavery: "I disagree because women aren't objects like currency. On the other hand, the gifts are worthless because he's going to die".

When providing a list of arguments and opinions, they are used to following a structured set of ideas: “(...) on the other hand I think that Aquiles doesn't have to be so so resentful and could do it for his mother".

When showing disagreemen twith Aquiles, a student structured his main arguments in two, as can be seen in the following quote.

In this paragraph they made a dinner for Aquiles so he would fight in the war. On the one hand I don't agree with women, with the thing about women, that he can choose whomever he wants, and on the other hand I think Aquiles could help his homeland

\section{Grammar-related Skills}

Last, grammar-related skills have been identified. The most recurring ones are connectives, which have been found throughout the whole transcriptions. Connectives such as "moreover", "for example", "first", "although", "however", "therefore" and so on are found all over the transcriptions.

To a lesser extent, derived words have been found, such as "resentful", "surely", "valuable", among others. From the derived words, a few 
nominalizations have been found, such as "the elder", "the recruit", "disagreement" or "present".

\section{Discussion and Conclusions}

As literature in the field of educational linguistics points out, it is necessary for students to master academic language and literacy skills and be familiar with the school's discourse in order to achieve academic success and, therefore, to have more opportunities to succeed outside school (Cummins, 1979; Cummins, 2008; Snow \& Uccelli, 2009; Uccelli et al., 2015a). Nevertheless, not all children have the same opportunities for developing school-relevant language and literacy skills, and it has been found that children from low SES backgrounds have less interactions with the texts and discourses which contribute to their acquisition of such skills (Snow et al., 1998; Fang et al., 2006; Uccelli et al., 2015a, 2015b).

Fortunately, Dialogic Literary Gatherings are breaking down the barriers those children often face. In DLGs, students from diverse SES backgrounds, ages, cultures and nationalities enjoy high-quality interactions with their peers while reading and commenting age-appropriate universal classics of literature. This constant exposure to rich literary texts and debates which are relevant not only for succeeding at school, but also in professional and social life, contributes to students' use of several schoolrelevant language and literacy skills reported by a number of scholars in the field.

Results from this exploratory study show that some school-relevant language and literacy skills reported by a number of scholars in the field emerge in a DLG with a group of 11 to 13 year old students from three different nationalities. In these gatherings students are used to constantly express ideas, feelings and thoughts, relating them to the texts and their own lives. Moreover, the egalitarian dialogue DLGs are grounded in makes students always look for arguments to support their claims with.

Research shows that in order to develop school-relevant language and literacy skills, students need a great exposure to academic and cognitively challenging texts (Fang et al., 2006; Lawrence et al., 2010; Uccelli et al., 2015b). The language and issues universal classics of literature contain and which appear throughout the DLGs contribute to their emergence. Indeed, 


\section{Lopez de Aguileta - School-relevant language}

results of this study show that when explaining their ideas regarding the books, children use connectives all over the debate. In Uccelli et al.'s (2015a, 2015b) concept of CALS, connectives are described as an important skill in school-relevant language. CALS also refers to other skills such as nominalizations and other morphologically derived words, which have also appeared in our results. Another important language skill to which Uccelli et al. (2015a, 2015b) and other scholars in the field give importance is the discourse structure. When expressing their ideas, students in the DLGs use structured arguments and reasoning linked with several connectives.

In a society in which language and social interaction play an increasing central role in our lives, where communicative skills become more and more complex, children need to be able to make judgements and arguments, not only for academic success, but also for professional, personal and social success. From the moment in which students start DLGs, they know that if they want to talk and explain why they have chosen a certain paragraph, they need to prove reasoning and arguments to support their explanations. The DLGs observed allow researchers to see how used they are to using arguments and constructing judgements and values, as almost half of the interactions made by students contained either arguments or judgements or both.

Moreover, DLGs train students to develop a critical mind (Fang et al., 2006) as they often relate the readings and their classmates' opinions with present and daily situations they see and experience, often showing disagreement with the text or with society.

One of the study's limitations is that it does not determine whether it is the classic texts, the egalitarian dialogues, or both, which propel the emergence of school-relevant language skills. Further research is needed in order to deepen on the elements which favor the emergence of such skills. Moreover, the study has not focused on finding the relationship between the emergence of academic language skills in DLGs and academic success. More evidence would be needed to find a direct relationship with the development of school-relevant language and literacy skills in DLGs and good academic outcomes. Another limitation is that the study has not compared the emergence of such skills in DLGs implemented in different 
school contexts and groups. More research with a bigger sample would be needed so that results in this study can be generalized to a wider population.

\section{References}

Alvarez, P., García-Carrión, R., Puigvert, L., Pulido, C., \& Schubert, T. (2018). Beyond the walls: The Social Reintegration Of Prisoners Through The Dialogic Reading Of Classic Universal Literature in Prison. International Journal of Offender Therapy and Comparative Criminology, 62(4), 1043-1061. doi: https://doi.org/10.1177/0306624X16672864

Aubert, A. (2015). Amaya: Dialogic Literary Gatherings evoking passion for learning and a transformation of the relationship of a Roma girl with her classmates. Qualitative Inquiry, 21(10), 858-864. doi: 10.1177/1077800415614034

Bakhtin, M. (1981). The dialogic imagination: four essays. University of Texas Press.

Bruner, J. S. (1996). Culture of education. Cambridge, MA: Harvard University Press.

Cummins, J. (1979). Cognitive/academic language proficiency, linguistic interdependence, the optimum age question and some other matters. Working Papers on Bilingualism, 19, 121-129.

Cummins, J. (2008). BICS and CALP: Empirical and theoretical status of the distinction. In N. Hornberger (Ed.), Encyclopedia of language and education (487-499). New York, NY: Springer.

de Botton, L., Girbés, S., Ruiz, L., \& Tellado, I. (2014). Moroccan Mothers' Involvement in Dialogic Literary Gatherings in a Catalan Urban Primary School: Increasing Educative Interactions and Improving Learning. Improving Schools, 17(3), 241-249. doi: https://doi.org/10.1177/1365480214556420

Fang, Z., Schleppegrell, M., \& Cox, B. (2006). Understanding the language demands of schooling: Nouns in academic registers. Journal of Literacy Research, 38(3), 247-273. doi: https://doi.org/10.1207/s15548430j1r3803_1 
Flecha, R. (2000). Sharing words: Theory and practice of dialogic learning. Lanham, MD: Rowman \& Littlefield.

Flecha, R. (2014). Using Mixed Methods From a Communicative

Orientation: Researching With Grassroots Roma. Journal of Mixed Methods Research, 8(3), 245-254.

https://doi.org/10.1177/1558689814527945

Flecha García, R., García Carrión, R., \& Gómez González, A. (2013).

Transfer of dialogue-based literary gatherings to prisons. Revista de

Educacion, 360, 140-161. doi: 10.4438/1988-592X-RE-2013-360-

224

García-Carrión, R. (2015). What the Dialogic Literary Gatherings Did for

Me: The Personal Narrative of an 11-Year-old Boy in a Rural

Community in England. Qualitative Inquiry, 21(10), 913-919. doi:

https://doi.org/10.1177/1077800415614305

García-Carrión, R., \& Villardón-Gallego, L. (2016). Dialogue and

Interaction in Early Childhood Education: A Systematic Review.

REMIE -Multidisciplinary Journal of Educational Research, 6(1),

51- 76. doi: 10.17583/remie.2016.1919

Garcia Yeste, C., Padrós, M., Monderjar, E., \& Villarejo, B. (2017). The Other Women in Dialogic Literary Gatherings. Research on Ageing and Social Policy, 5(2), 181-202. doi: 10.4471/rasp.2017.2660

Garcia Yeste, C., Gairal Casado, R., Munté Pascual, A., \& Plaja Viñas, T.

(2017). Dialogic literary gatherings and out-of-home child care:

Creation of new meanings through classic literature. Child \& Family

Social Work, 23(1). doi: https://doi.org/10.1111/cfs.12384

Goldman, S. R. (2012). Adolescent literacy: learning and understanding content. The Future of Children, 22(2), 89-116. Retrieved from http://www.ncbi.nlm.nih.gov/pubmed/23057133

Gómez, A., Puigvert, L., \& Flecha, R. (2011). Critical Communicative Methodology: Informing Real Social Transformation Through

Research. Qualitative Inquiry, 17(3), 235-245. doi:

https://doi.org/10.1177/1077800410397802

Habermas, J. (1984). The theory of communicative action. Beacon Press.

Hargreaves, L., \& García-Carrión, R. (2016). Toppling Teacher Domination of Primary Classroom Talk through Dialogic Literary Gatherings in 
England. FORUM 58(1), 15-25. doi:

http://dx.doi.org/10.15730/forum.2016.58.1.15

INCLUD-ED (2006-2011). Strategies for Inclusion and Social Cohesion in

Europe from Education. 6th Framework Programme. Citizens and

Governance in a Knowledge-Based Society. CIT4-CT-2006-028603.

Directorate-General for Research, European Commission.

Lawrence, J., White, C., \& Snow, C. (2010). The Words Students Need.

Educational Leadership, 68(2), 22-26. Retrieved from

https://escholarship.org/uc/item/46v4m4z0

Levy, R., Hall, M. \& Preece, J. (2018). Examining the Links between

Parents' Relationships with Reading and Shared Reading with their

Pre-School Children. International Journal of Educational

Psychology, 7(2), 123-150. doi:10.17583/ijep.2018.3480

Mello, R. R. D., \& Braga, F. M. (2018). School as Learning Communities:

An Effective Alternative for Adult Education and Literacy in Brazil.

Frontiers in Education. 3, 114. doi:

https://doi.org/10.3389/feduc.2018.00114

Meneses, A., Uccelli, P., Santelices, M. V., Ruiz, M., Acevedo, D., \&

Figueroa, J. (2017). Academic Language as a Predictor of Reading

Comprehension in Monolongual Spanish-Speaking Readers:

Evidence From Chilean Early Adolescents. Reading Research

Quarterly, 53(2), 223-247. doi: https://doi.org/10.1002/rrq.192

Mercer, N. (2000). Words and Minds. London and New York: Routledge.

Oliver, E., \& Gatt, S. (2010). De los actos comunicativos de poder a los actos comunicativos dialógicos en las aulas organizadas en grupos interactivos. Revista Signos, 43(2), 279-294.

Serrano, M. A., Mirceva, J., \& Larena, R. (2010). Dialogic imagination in literacy development. Revista de Psicodidáctica, 15(2), 191-205. doi:10.1387/RevPsicodidact.820

Snow, C. E., Cancini, H., Gonzalez, P., \& Shriberg, E. (1989). Giving formal definitions: An oral language correlate of school literacy. In D. Bloome (Ed.), Classrooms and literacy (233-249). Norwood, NJ: Ablex.

Snow, C., \& Uccelli, P. (2009). The challenge of academic language. In D.R. Olson \& N. Torrance (Eds.), The Cambridge handbook of literacy (112-133). New York, NY: Cambridge University Press. 
Snow, C.E., Lawrence, J., \& White, C. (2009). Generating knowledge of academic language among urban middle school students. Journal of Research on Educational Effectiveness, 2(4), 325-344. doi:10.1080/19345740903167042

Soler, M. (2015). Biographies of "Invisible" People Who Transform Their Lives and Enhance Social Transformations Through Dialogic Gatherings. Qualitative Inquiry, 21(10). 839-842. doi: 10.1177/1077800415614032

Uccelli, P., Phillips Galloway, E., Barr, C., Meneses, A., \& Dobbs, C. (2015a). Beyond vocabulary: Exploring cross-disciplinary academic-language proficiency and its association with reading comprehension. Reading Research Quarterly, 50(3), 337-356. doi: https://doi.org/10.1002/rrq.104

Uccelli, P., Barr, C., Dobbs, C., Phillips Galloway, E., Meneses, A., \& Sánchez, E. (2015b). Core academic language skills: An expanded operational construct and a novel instrument to chart schoolrelevant language proficiency in preadolescent and adolescent learners. Applied Psycholinguistics, 36(5), 1077-1109. doi: https://doi.org/10.1017/s014271641400006x

Valdez-Menchaca, M. C., \& Whitehurst, G. J. (1992). Accelerating language development through picture book reading: A systematic extension to Mexican day care. Developmental Psychology, 28(6), 1106-1114. doi: 10.1037/0012-1649.28.6.1106

Villardón-Gallego, L., García-Carrión, R., Yánez-Marquina, L., \& Estévez, A. (2018). Impact of the Interactive Learning Environments in Children's Prosocial Behavior. Sustainability, 10(2138), 1-12. doi:10.3390/su10072138

Vygotsky, L. (1962). Thought and language. Cambridge, MA, US: MIT Press.

Vygotsky, L. (1978). Mind in society: the development of higher psychological processes. Cambridge, MA: Harvard University Press. 
Garazi Lopez de Aguileta is Research Assistant at CREA at the University of Barcelona

Orcid ID: https://orcid.org/0000-0001-7571-3556

Contact Address: Passeig Vall d'Hebron, 171. 08035. Email: glopezdeaguileta@ub.edu 